\title{
HEMICHOREA/HEMIBALISMUS DENGAN HIPERGLIKEMIA NONKETOTIK PADA STROKE ISKEMIK AKUT
}

\author{
HEMICHOREA/HEMIBALLISM ASSOCIATED WITH NONKETOTIC \\ HYPERGLYCEMIC ON ACUTE ISCHEMIC STROKE
}

Safridawati, * Hidayaturrahmi, *Natasya Wanda, * Nova Dian Lestari, * Syahrul*

\begin{abstract}
Hemichorea/hemiballism (HCHB) associated with nonketotic hyperglycemia in acute ischemic stroke is a wellrecognized syndrome characterized by the sudden occurrence of hemichorea or more severe expression like hemiballism. The hyperkinetic movements involve the face, arm, or leg. HCHB in acute ischemic stroke is a movement disorder that is rarely reported with hyperkinetic movement. This case report aimed to describe patient with HCHB associated with hyperglycemia as prior sign of stroke ischemic and propose a possible pathophysiology. We report three patients who had HCHB accompanied by hemiparesis, facial and hypoglossus nerve palsy. Laboratory results showed increased serum glucose levels and negative urine ketones. Imaging findings of head CT scan found an infarction in the basal ganglia. Patients are treated with antiplatelet and or anticoagulant therapy and correction of hyperglycemia with additional therapy of dopamine receptor antagonist. The combination of a recent or old striatal lesion and hyperglycemia induce HCHB, causing increased inhibition of the subthalamic nucleus and causing decreased GABAergic inhibition of the thalamus. Diabetes mellitus should always be suspected in patients who develop HCHB movements. When hyperglycemia is detected and treated, movement disorders resolve within a few days and the administration of dopamine receptor antagonists can be considered.
\end{abstract}

Keywords: Hemiballism, hemichorea, hyperglycemia, ischemic stroke

\section{ABSTRAK}

Hemichorea/hemibalismus (HCHB) yang berhubungan dengan hiperglikemia nonketotik pada stroke iskemik akut adalah sindrom yang ditandai oleh munculnya hemichorea yang terjadi secara tiba-tiba atau disertai dengan gejala yang lebih berat, seperti hemibalismus. Pergerakan hiperkinetik meliputi wajah, lengan dan tungkai. HCHB pada stroke iskemik akut merupakan gangguan pergerakan hiperkinetik yang jarang dilaporkan. Laporan kasus ini bertujuan untuk menggambarkan pasien yang mengalami keluhan HCHB sebagai gejala awal terjadinya stroke iskemik disertai dengan hiperglikemia dan memperkirakan penjelasan patofisiologi yang mungkin terjadi pada pasien ini. Kami melaporkan tiga pasien dengan keluhan HCHB sebagai gejala awal stroke iskemik akut yang disertai hiperglikemia. Pada ketiga kasus tersebut keluhan disertai dengan paresis nervus fasialis, hipoglossus serta hemiparesis ekstremitas kontralateral lesi. Kadar glukosa serum meningkat dan keton urin negatif. Gambaran CT scan menunjukkan adanya infark di ganglia basalis. Pada tata laksana kami menemukan bahwa koreksi hiperglikemi disertai pemberian terapi antikoagulan dan atau antiplatelet serta agen neuroleptik dapat menyebabkan perbaikan luaran pada gejala HCHB secara perlahan. Kombinasi lesi striatal baru dan hiperglikemia dapat menginduksi terjadinya HCHB karena kedua hal tersebut dapat menyebabkan peningkatan inhibisi inti subtalamik dan gangguan inhibisi GABAergic talamus. Diabetes melitus harus selalu dicurigai pada pasien dengan keluhan HCHB. Ketika hiperglikemia terdeteksi dan ditatalaksana, gangguan gerakan menghilang dalam beberapa hari dan dapat dipertimbangkan dengan pemberian terapi neuroleptik.

Kata kunci: Hemibalismus, hemichorea, hiperglikemia, stroke iskemik

*Prodi/Bagian Neurologi Fakultas Kedokteran Universitas Syiah Kuala/RSUD Dr. Zainoel Abidin, Banda Aceh, Indonesia. Korespondensi: safridawatidr@gmail.com

\section{PENDAHULUAN}

Hemichorea/hemibalismus (HCHB) merupakan keadaan yang jarang ditemukan, chorea merupakan gerakan involunter abnormal yang ditandai dengan gerakan singkat, tiba-tiba dan tidak teratur dan dalam keadaan lebih berat bisa terjadi balismus yaitu gerakan mendadak dan kuat dari ekstremitas, leher dan badan, yang mengenai satu sisi dari tubuh atau melibatkan satu ekstremitas (monobalismus). Keadaan ini berhubungan dengan infark kecil atau perdarahan di sekitar inti subtalamus. HCHB pada stroke iskemik akut merupakan gangguan pergerakan hiperkinetik yang jarang dilaporkan. ${ }^{1-3}$ Insidensi HCHB pada stroke iskemik akut antara $0,4 \%-0,54 \%$ dengan prevalensi $1 \%{ }^{3}$

Lesi pada salah satu hemisfer serebri menyebabkan gangguan gerak kontralateral. Pergerakan hiperkinetik meliputi wajah, lengan, dan tungkai yang sama. Nukleus subtalamikus mempunyai hubungan dengan nucleus rubber, substansia nigra 
dan globus palidus dari ganglia basalis. Fungsinya belum diketahui secara jelas, tetapi lesi pada nukleus subtalamikus dapat menimbulkan diskinesia yang lebih berat seperti HCHB. Berbagai kondisi seperti penyakit neurodegeneratif, serebrovaskular, imunologi, neoplastik, infeksi, dan kelainan metabolik dikenal sebagai penyebab sekunder dari HCHB. ${ }^{4}$

Ingle dan Gupta tahun 2016 melaporkan bahwa stroke iskemik akut biasanya ditandai dengan gejala seperti paresis/paralisis anggota gerak atau kebas. Adapun gejala yang jarang terjadi pada stroke iskemik akut adalah gangguan gerak hiperkinetik seperti HCHB, mioklonus, tics, dan tremor rubral. ${ }^{4}$

Laporan kasus ini bertujuan untuk menggambarkan pasien yang memiliki keluhan HCHB sebagai gejala awal terjadinya stroke iskemik disertai dengan hiperglikemia dan memperkirakan penjelasan patofisiologi yang mungkin terjadi pada pasien ini.

\section{KASUS}

Kasus pertama: Tn. A, usia 63 tahun datang ke Instalasi Gawat Darurat (IGD) dengan keluhan gerakan yang tidak dapat dikontrol yang kuat dan cepat pada lengan dan tungkai kanan secara tiba-tiba. Gerakan tersebut terjadi sejak 20 hari sebelum masuk rumah sakit yang disertai oleh mulut merot dan bicara pelo secara bersamaan. Pada pemeriksaan neurologi didapatkan paresis nervus fasialis dan nervus hipoglosus sentral kanan, motorik ekstremitas kanan sulit diperiksa karena gerakan involunter tersebut. Terdapat riwayat DM tipe 2, selama 10 tahun namun tidak terkontrol. Tidak ada riwayat keluarga dengan gangguan gerak. Kadar glukosa darah sewaktu adalah $450 \mathrm{mg} / \mathrm{dL}$, nilai HbAlc adalah $10,8 \%$, glukosa urin +3 dan keton urin negatif. Hasil CT scan kepala terdapat infark di ganglia basalis sinistra disertai atropi serebri. Pasien diberikan terapi enoxaparin $0,6 \mathrm{mg} / 12 \mathrm{jam}$, haloperidol $2 \times 0,5 \mathrm{mg}$ serta regulasi gula darah menggunakan drip insulin aspart dengan dosis $2 \mathrm{cc} / \mathrm{jam}$. Setelah dirawat selama 1 minggu, pasien mengalami perbaikan sebagian dan pulang berobat jalan.

Kasus kedua: Tn JS, usia 51 tahun datang dengan gerakan involunter yang kuat dan tidak teratur pada lengan dan tungkai kiri sejak 13 hari sebelum masuk rumah sakit secara tiba-tiba saat aktivitas. Gerakan tersebut disertai bicara pelo dan bibir merot. Selain itu pasien juga mengeluhkan tangan dan kaki kiri lebih lemah dikarenakan gangguan gerak tersebut, dibandingkan tangan dan kaki kanan. Kadar glukosa darah sewaktu saat awal terjadi gangguan adalah $455 \mathrm{mg} / \mathrm{dL}$ dan keton urin negatif. Hasil CT scan kepala didapatkan kesan parenkim otak dalam batas normal, sedangkan MRI kepala dengan kontras didapatkan infark akut di ganglia basalis kanan dan nukleus kaudatus kanan. Pasien mempunyai riwayat penyakit DM tipe 2 yang tidak terkontrol. Pasien diberikan terapi clopidogrel 1x75mg, citicolin 500mg /12jam, haloperidol $2 \times 0,5 \mathrm{mg}$ oral, serta regulasi gula darah dengan menggunakan insulin gargline 10 unit per hari dan insulin aspart $3 \times 8$ unit. Pasien mengalami perbaikan sebagian dan bisa pulang berobat jalan setelah dirawat selama 10 hari.

Kasus Ketiga: Tn R, laki-laki 44 tahun dibawa ke rumah sakit dengan gerakan involunter yang kuat dan tidak teratur pada lengan dan kaki kanan yang terjadi secara tiba-tiba 4 jam saat aktivitas. Keadaan tersebut diikuti oleh paresis nervus fasialis kanan tipe sentral. Pasien memiliki riwayat penyakit DMtipe 2 namun tidak terkontrol. Kadar glukosa darah sewaktu adalah $264 \mathrm{mg} / \mathrm{dL}$ dan keton urin negatif. Hasil CT scan kepala tidak menunjukkan adanya infark, dikarenakan pasien dilakukan CT scan kepala pada saat akut kurang dari 6 jam sehingga belum terlihat daerah infark. Pasien kemudian diberikan terapi injeksi enoxaparin $0,6 \mathrm{mg} / 24 \mathrm{jam}$ dan citicolin $500 \mathrm{mg} / 12$ jam, serta obat-obatan oral berupa haloperidol $2 \times 0,5 \mathrm{mg}$. Regulasi gula darah dengan meggunakan insulin aspart 3x6 unit. Pasien dirawat selama 7 hari mengalami perbaikan sebagian dan pulang dengan berobat jalan (Gambar 1).

\section{PEMBAHASAN}

Angka kejadian HCHB sebagai gejala penyerta stroke dapat dijumpai pada $0,4 \%-0,54 \%$ kasus dalam 100.000 penderita stroke per tahunnya. ${ }^{5}$ Chorea/ balismus yang berhubungan dengan hiperglikemia pertama kali dijelaskan oleh Bedwell pada tahun 1960, tetapi laporan kasus yang terkait hal tersebut masih sangat jarang, masih kurang dari 200 kasus. Trias umum yang terjadi pada kasus ini adalah gerakan 


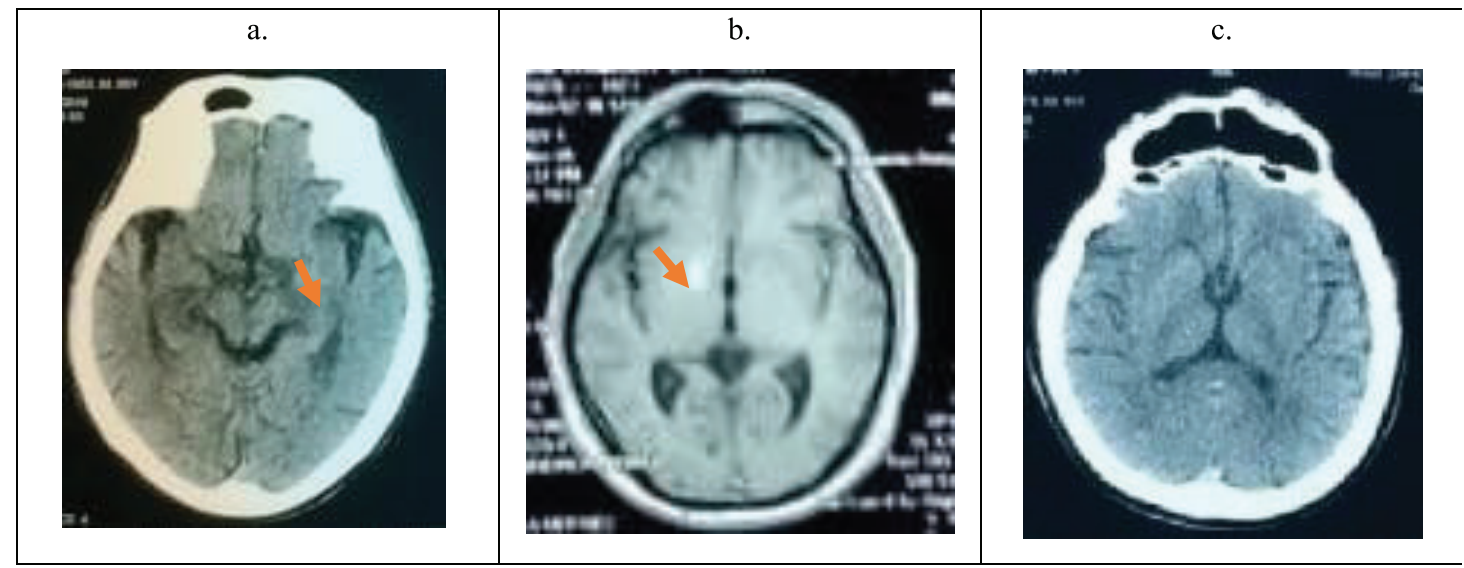

Gambar 1. Gambaran CT Scan Kepala (1a dan 1c) dan MRI Kepala (1b)

Gambar (1a) kasus 1 dengan infark di ganglia basalis kiri (tanda panah merah) disertai atropi, gambar (1b) kasus 2 dengan infark hiperakut di ganglia basalis kanan dan nukleus kaudatus kanan (tanda panah merah), gambar (1c) kasus 3 tidak menunjukkan adanya infark.

involunter unilateral (atau bilateral), kontralateral (atau bilateral), gambaran abnormalitas striatal pada pencitraan dan hiperglikemia pada pasien DM baik yang sudah diketahui atau yang baru diketahui. ${ }^{2}$ Belum ada penelitian epidemiologis, tetapi perkiraan prevalensi kasus ini sebesar $1 \%$. Rasio perempuan dibanding laki-laki adalah 1,8:1 dan usia tua memiliki faktor risiko besar. Usia rata-rata saat onset adalah sekitar 70 tahun (sekitar 22-90 tahun). 2,4

Chang dkk menyimpulkan bahwa gejala HCHB dapat dibagi menjadi dua tipe; common type yaitu pasien dengan diabetes, peningkatan kadar gula darah, keton urin yang negatif, chorea unilateral atau bilateral dan ditemukan kelainan pada hasil MRI dan CT scan kepala, dimana tipe ini merupakan gejala yang tersering. Sedangkan uncommon type dimana pasien dengan diabetes, peningkatan kadar gula darah, keton urin yang negatif, chorea unilateral atau bilateral dan tanpa kelainan pada radiologi MRI dan CT scan kepala, yang relatif tidak umum pada HCHB. $^{4}$

Gerakan abnormal dapat diklasifikasikan dari chorea ringan hingga balismus berat berdasarkan jenis dan tingkat keparahannya. Sebagian besar laporan kasus yang dipublikasikan menggunakan istilah hemichorea atau hemibalismus karena keterlibatan bilateral terjadi pada kurang dari 10\% kasus. Pada serial kasus ini, tiga pasien mengalami gerakan involunter yang berhubungan dengan hiperglikemia yang diikuti oleh paresis nervus fasialis sebagian paresis nervus hipoglosus disertai hemiparesis yang merupakan gejala awal dari stroke iskemik. ${ }^{3-4}$

Gerakan involunter proksimal unilateral sering dikaitkan dengan lesi nukleus subtalamikus. Nukleus tersebut berguna dalam neurotransmiter eksitatori glutamat yang berfungsi sebagai input eksitatori utama ke bagian medial globus palidus, dengan diinhibisi oleh gamma mino butyric acid (GABA) terhadap aktivitas talamus ventrolateral. Kerusakan nukleus subtalamikus menyebabkan penurunan fungsi inhibisi dan meningkatkan eksitasi talamus motorik dan korteks premotorik, menghasilkan gerakan involunter (Gambar 2)., ${ }^{1,5}$ Hiperglikemia dapat menginduksi perubahan perfusi pada striatum kontralateral dan kerusakan pada GABA, sehingga menyebabkan inhibisi berlebihan pada nukleus subtalamikus dan eksitatori pada output kortikal. ${ }^{1}$

Pasien yang mengalami HCHB yang memiliki penyakit penyerta berupa hiperglikemia, setelah kadar hiperglikemi dikoreksi secara baik terbukti terjadi perbaikan secara perlahan pada gerakan involunter. Hal ini sesuai dengan yang dilaporkan oleh Postuma dan Lang tahun 2013 bahwa dari 100 kasus HCHB dengan nonketotik hiperglikemia, setelah koreksi kadar gula darah, pasien mengalami perbaikan gejala selama beberapa hari sampai beberapa minggu walaupun $20 \%$ kasus dilaporkan terdapat gejala ringan yang menetap selama lebih dari 3 bulan. Hal ini menunjukkan bahwa 


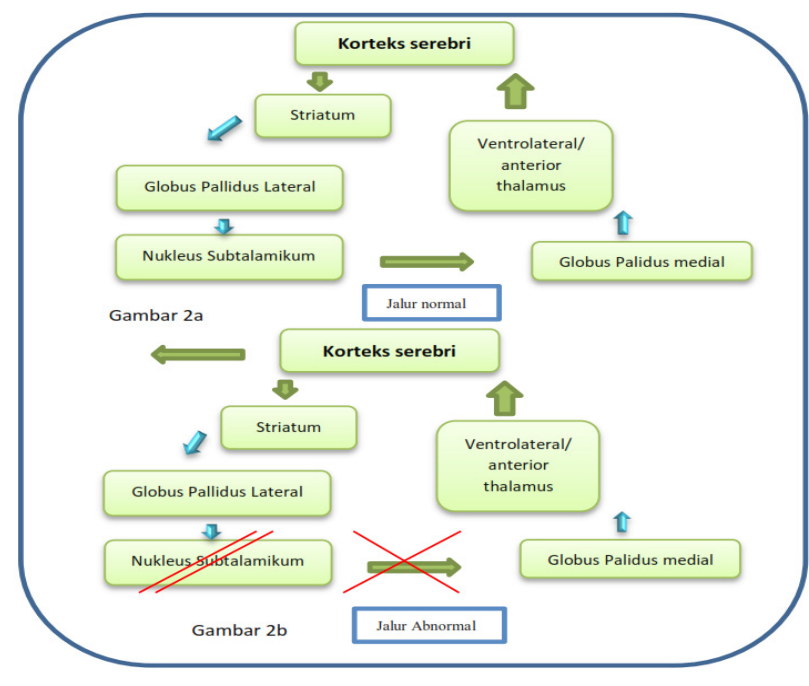

Gambar 2. Gerakan Involunter

Jalur normal indirek dari sirkuit korteks-basal ganglia-talamus ditunjukkan pada (Gambar 2a). Lesi pada nukleus subtalamikus (gambar 2b) mengganggu eksitasi globus palidus bagian medial, sehingga mengurangi pengaruh penghambatannya pada talamus ventrolateral dan ventroanterior. Peningkatan eksitasi yang dihasilkan dari korteks motorik dan tambahan menimbulkan HCHB. ${ }^{6}$

kadar gula darah tanpa dijumpai adanya keton didalam darah maupun urin. Beberapa penelitian menyebutkan HCHB pada nonketotik hiperglikemia berhubungan dengan insidensi timbulnya stroke iskemik pada fase akut perjalanan penyakitnya, yang dalam hal ini ditegakkan melalui pemeriksaan CT scan kepala. Lesi biasanya menghilang seiring dengan normalisasi CT scan atau MRI kepala, tetapi pada beberapa kasus lesi tetap ada meskipun ada resolusi klinis HCHB. Penelitian lebih lanjut diperlukan untuk memperjelas perbedaan ini. Patofisiologi yang tepat dari lesi ini tetap menjadi misterius. Laporan kasus gerakan involunter pada semua subjek pada laporan kasus ini mengalami hiperglikemia pada saat onset HCHB. DM Tipe 2 sering dikaitkan dengan gangguan ini. HCHB perlahan membaik pada beberapa hari setelah koreksi kadar gula darah .

Pada laporan kasus yang dilakukan oleh Si Lei Fong dkk tahun 2019 menyebutkan bahwa pemberian neuroleptik pada pasien HCHB dengan hiperglikemia menunjukkan perbaikan dari gejala klinis dari HCHB. Tata laksana pada kasus HCHB dengan hiperglikemia menggunakan terapi neuroleptik seperti haloperidol sering digunakan dengan tujuan untuk mempercepat gejala resolusi gerakan involunter, namun masih perlu dilakukan penelitian secara lebih lanjut. ${ }^{6}$

\section{KESIMPULAN}

Hemichorea/hemibalismus yang berhubungan dengan hiperglikemia nonketotik dapat terjadi bersamaan onset awal stroke iskemik. Meskipun patofisiologi dari gangguan gerak ini masih belum dapat ditetapkan secara pasti, namun penatalaksanaan yang cepat dan akurat dapat memberikan luaran yang baik bagi pasien. Regulasi gula darah, terapi definitif stroke iskemik serta kombinasi obat-obatan neuroleptik dapat memberikan hasil yang maksimal pada pasien.

\section{DAFTAR PUSTAKA}

1. Postuma RB, Lang AE. Movement disorder emergencies diagnosis and treatment. Edisi ke-2. New York: Humana Press; 2013. h. 151-60.

2. Cosentino C, Torres L, Nun Y, Suarez R, Velez M, Flores M. Hemichorea/hemiballism associated with hyperglycemia: report of 20 cases. Tremor other Hyperkinetic Mov. 2016;6:1-4.

3. Ingle V, Gupta R. Acute subthalamic stroke presenting as hemiballismus: a review of literature. Int $\mathrm{J}$ Sci Study. 2016;4(3):218-9.

4. Chang X, Hong W, Yu H, Yao Y. Chorea associated with nonketotic hyperglycemia. Medicine (Baltimore). 2017;96(45):1-2.

5. Patel AR, Patel AR, Desai S. Acute hemiballismus as the presenting feature of parietal lobe infarction. Cureus. 2019;11(5):1-9.

6. Fong SL, Tan AH, Lau KF, Ramli N, Lim S. Hemiballismus with Predominant ipsilateral putaminal abnormality on neuroimaging. J Mov Disord. 2019; 12(3):187-9. 